\title{
Profit efficiency development of Islamic Banking using the stochastic frontier approach
}

\author{
Zubaidah Nasution \\ STIE Perbanas Surabaya, Surabaya, Indonesia \\ e-mail: zubaidah@perbanas.ac.id
}

Keywords:

Efficiency, SFA, total profit

\section{Article History}

Received: 21 January 2020

Accepted: 27 January 2020

Published: 7 February 2020

DOI:

$\underline{\text { 10.20885/JEKI.vol6.iss1.art6 }}$

JEL: E44, G21, P34, Z12

\begin{abstract}
This study aims to analyze the efficiency of Islamic banking with a stochastic frontier analysis (SFA) on 10 Islamic banks from 2011 to 2018. The research variables consist of input variables total profits, third party funds and personnel expenses and output variable total financing and murabahah receivables. This research method uses SFA to measure the efficiency of Islamic banks and the influence between variables. The results of this study indicate the average efficiency of Islamic banks has not reached $100 \%$ or at $82.24 \%$. Variable third party funds, personnel expenses have a positive effect on total profits while total financing and murabahah receivables have a negative effect on total profits.
\end{abstract}

\section{Cited This:}

Nasution, Z. (2020). Profit efficiency development of Islamic Banking using stochastic frontier approach. Jurnal Ekonomi dan Kenangan Islam, 6(1), 55-63. DOI: 10.20885/JEKI.vol6.iss1.art6

\section{Introduction}

Islamic banking annually experiences growth rates and market share of Islamic banking shows high performance and high market levels. The Chairman of OJK (Indonesia Financial Services Authority) revealed that the performance of Islamic banking reflected by the position of Islamic banking assets which recorded growth of $20.65 \%$ annually or year on year (yoy) at the end of February 2018 to Rp 429.36 trillion. Meanwhile, financing is still moving to a double-digit level of $14.76 \%$ yoy to Rp 289.99 trillion. In the first two months of 2018, Wimboh explained that there had been an increase in accounts to 560 Islamic banking accounts from the end of December 2017. This was also supported by an increase in the number of sharia commercial bank (BUS) and sharia business units (UUS). In February 2018, there are 13 sharia commercial banks, 21 sharia business units and 167 sharia rural banks (BPRS). This growth is supported by sharia capital which is classified as good, reflected by the sharia public CAR ratio of $18.62 \%$ and nonperforming financing of $4.31 \%$ which is still maintained below the $5 \%$ threshold. Islamic bank liquidity is still relatively high from the threshold. It can be seen from the position of third party funds that raised up 16.1\% yoy to Rp 339.05 trillion (Kompas, 2019). According to Adiwarman in 2018 there will also be two more BUS (Sharia commercial bank) going up to BOOK III (Indonesian bank level). Additional assets from the establishment of state-owned Islamic banks, mergers and conversions could increase the share of the Islamic banking market by around eight percent (Republika, 2019).

Aside from the performance ratio which is the impetus of the National Islamic Finance Committee (KNKS) on the growth of Islamic banking, the initiation of the formation of large Islamic state-owned banks, zakat integration, and the development of halal lifestyles has an impact on Islamic banking. The positive impact is also brought by the development of the role of waqf through Sharia microfinance institutions (LKMS) 'Bank Waqf'. From the performance and 
programs implemented by the government, it is expected to obtain a high market share in the community and eliminate the community's assessment of Islamic banking which is the same as conventional banking. The efforts presented above are in line with the objectives of implementing the AEC (ASEAN Economic Community) program which has been implemented since 2015. The ability of Islamic banks in responding to the AEC has been well implemented in terms of high growth of Islamic banking assets and capital and human resources that are able to compete in the global market. The problems of Islamic banking before AEC were found in sharia human resources which had been covered up a lot by conventional human resources which were still scientifically very minimal, especially in the field of sharia. The improvement in HR was followed by the addition of Islamic commercial banks.

Islamic banking performance can also be seen from the efficiency of Islamic banks, the more efficient a bank, the more liability the bank has. Based on the results of previous studies, Sharia commercial bank shows a high level of efficiency Rahmawati (2015), Wahab (2015), Hosen \& Muhari (2014). However, it contradicts with the results of the previous study which shows that Islamic commercial banks have a low efficient rate compared to Islamic rural bank (Effendi, 2016) and conventional banks (Oktavi, 2018).

The profit efficiency of Islamic banks is on average $93.41 \%$ below $100 \%$, this shows a good and efficient performance in Islamic banks Suhel (2011). Overall, the results show that Islamic Bank Malaysia has an average profit efficiency of $67.34 \%$. BPRS has a high level of efficiency (Effendi, 2016; Nuryartono et al., 2012). BPRS efficiency is still very volatile (Naufal \& Firdaus, 2017). Other research results on 5 BPRS, BPRS Central Syari'ah Utama are inefficient while BPRS Dana Amanah, BPRS Dana Mulia, BPRS Harta Insan Karimah were inefficient in the first quarter of 2016 (Ramadhan et al., 2017).

Research of Tahir \& Haron (2010) suggests that the Islamic banks of Africa, the Far East and Central Asia, Europe and the Middle East are relatively better at monitoring cost and profit efficiency. Efficiency of Conventional versus Islamic Banks the cost and profit efficiency of 80 banks in 21 of the Organization of Islamic Conference (OIC) countries shows that there is no significant difference between the efficiency of conventional banks and Islamic banks (Mohamad, et al., 2008). The results of research by Eisazadeh et al (2012) shows that banks in the Middle East and North Africa, The Middle East and North Africa can operate efficiently if the bank is able to save 20 percent of the total cost factors that affect efficiency production. Mongid and Muazaroh's (2017) using the SFA method of banking efficiency in Indonesia, Malaysia and Singapore is better than banking efficiency in Thailand. In general, efficiency in banks is influenced by bank size, crisis dummy, profitability, capital adequacy, total assets, and problem loans.

The efficiency of Islamic banking was previously measured by banking ratios such as operating expenses and operating income (BOPO). Based on these measurements shows that banks are considered not to have contributed greatly in increasing economic growth. According to the Secretary General of the Indonesian Islamic banking Association (Asbisindo) Achmad K Permana, 2018 is not a good year for Islamic banking to grow aggressively where the assumption of economic growth set by the government next year is not far from achieving national growth in 2017, which is still in the range of five percent.

From the above background this study aims to analyze the efficiency of Islamic banks with parametric input and output components and do not use bank ratio. The difference between this study and the previous researchers who also used parametric measurement, namely the efficiency of this study, was conducted with an intermediate approach based on the total profit of Islamic banks.

\section{Research Method}

This research is a quantitative study using secondary data. Quantitative research is an objective research approach, including the collection and analysis of quantitative data and using statistical 
testing methods (Hermawan, 2005). In this study a number of hypotheses were tested statistically so that they could be classified as testing hypothesis studies. Testing hypothesis research is research that tries to explain the nature of a particular relationship/influence, see certain differences in several groups, or the independence of two or more factors in a situation (Hermawan, 2005).

Population is a collection of objects that want to know their characteristics both from the results of measurements or qualitative and quantitative calculations. The population in this study are all Sharia Commercial Banks in Indonesia. The sample in this study is a Sharia Commercial Bank whose financial statements are available during the period of 2011-2018. The purposive sampling method with complete financial statement criteria is available in the year of the researcher, namely the statement of financial position, income statement and statement of changes in capital during the observation period. The measurement of variables in this study is described in Table 1.

Table 1. Research Variables and Operational Definition

\begin{tabular}{|c|c|c|c|}
\hline Variable type & Indicator & Operational Definition & Data source \\
\hline Dependent & Total Profit & $\begin{array}{l}\text { The net profit of the Islamic } \\
\text { bank after tax }\end{array}$ & Profit-Loss report \\
\hline Independent & Third party fund (P1) & $\begin{array}{l}\text { The amount of current } \\
\text { accounts and savings deposits } \\
\text { with a wadiah contract and the } \\
\text { number of temporary syirkah } \\
\text { funds consists of savings and } \\
\text { mudharabah contract deposits }\end{array}$ & $\begin{array}{l}\text { Statement of financial } \\
\text { position }\end{array}$ \\
\hline Independent & HR cost $(\mathrm{P} 2)$ & $\begin{array}{l}\text { Bank operational costs paid to } \\
\text { employees in the form of } \\
\text { salaries and benefits }\end{array}$ & Profit-Loss report \\
\hline Independent & Total financing (Q1) & $\begin{array}{l}\text { Financing the acceptance of } \\
\text { mudharabah and musharaka } \\
\text { shariah profits }\end{array}$ & $\begin{array}{l}\text { Statement of financial } \\
\text { position }\end{array}$ \\
\hline Independent & $\begin{array}{l}\text { Murabahah account } \\
\text { receivables (Q2) }\end{array}$ & $\begin{array}{l}\text { Margin of murabahah financing } \\
\text { distribution }\end{array}$ & Profit-Loss report \\
\hline
\end{tabular}

\section{Stochastic Frontier Approach (SFA)}

The SFA method was developed by (Berger \& Mester, 1997). Frontier 4.1 software is used to estimate the cost function using the panel data method on the Stochastic Frontier Approach (SFA) parametric approach. The standard stochastic cost frontier function has the following general form (log):

\section{$\ln C i=f(\ln X j i, \ln Y j i)$}

Where Ci is total cost of bank $n$; $\mathrm{Xji}$ is input $\mathrm{j}$ on bank $n$; Yji is output $k$ on bank $\mathrm{n}$; while $e \mathrm{i}$ is error term. $e i$ consist of 2 functions:

$e i=u i+v i$

where $u i$ are error factor which can be controlled; and $v i$ are random error factor which can be controlled. $\mathrm{V}$ is assumed to be distributed normally $\mathrm{N}(0, \sigma 2 \mathrm{v})$ and $\mathrm{u}$ distributed halfnormally, $|\mathrm{N}(0, \sigma 2 \mathrm{v})|$ where uit $=(\mathrm{ui} \exp (-\mathrm{h}(\mathrm{t}-\mathrm{T})) 3$ and $h$ is parameter which can be estimated. Cost efficiency is derived from a cost function by the shape of general equity (log) as follow:

$\ln C=f(w, y)+e$ 
By using the form of the stochastic cost frontier equation the cost equation can be written as follows:

$$
\ln C=f(w, y)+\ln u+\ln v
$$

where $\mathrm{C}$ is total cost or cost efficiency; $\mathrm{w}$ is input amount; $\mathrm{y}$ is output amount; while $u$ and $v$ are error term. So, cost efficiency can be written as follows

$$
\mathrm{CFFn}=\frac{c_{\min }}{c_{n}}=\frac{\exp \left[f c\left(w^{n} y^{n}\right)+\ln \left(u c_{\min }\right)\right]}{\exp \left[f c\left(w^{n} y^{n}\right)+\ln \left(u c_{n}\right)\right]}=\frac{u c_{\min }}{u c_{n}}
$$

Efficiency values calculated using the SFA method are percentage forms. Percentage that shows efficient intent is a percentage with a weight of $100 \%$. The closer it is to $100 \%$, the more efficient the banks are in using their inputs to produce maximum output.

\section{Result and Discussion}

This study uses the data of Islamic banking financial statements that are published on each of the websites of Islamic banks and financial services authorities (OJK). Islamic bank financial reports were obtained from 2011 to 2018. Based on OJK Islamic banking statistics the number of sharia commercial banks is 14 Islamic banks, in this study the sample of this study uses 10 sharia commercial banks which have annual financial reports that are regularly published on each website Islamic commercial banks.

Table 2. Research Sample

\begin{tabular}{cl}
\hline No & \multicolumn{1}{c}{ Bank Umum Syariah } \\
\hline 1 & Bank Muamalat \\
2 & BRI Syariah \\
3 & Jabar Banten Syariah \\
4 & Panin Syariah \\
5 & Mega Syariah \\
6 & Bukopin Syariah \\
7 & BCA Syariah \\
8 & BNI Syariah \\
9 & Maybank Syariah \\
10 & Victoria Syariah \\
\hline
\end{tabular}

Source: OJK 2019

Measurement of the efficiency of Islamic commercial banks is done by the SFA approach which is analyzed by the intermediation approach. The intermediation approach views banks as intermediaries that convert and transfer financial assets from surplus units to deficit units (Haddad, 2003). The level of efficiency is analyzed from the profit function model with the dependent variable total earnings, independent variables in the form of inputs consisting of third party funds (P1) and personnel expenses (P2) and output variables namely total financing (Q1) and murabahah receivables (Q2). Measurement of efficiency in the frontier model is done by changing each variable in the form $\ln$. Furthermore, the SFA output as a result of the efficiency of Islamic commercial banks, in the second analysis by looking at the effect of each independent variable on total earnings as the dependent variable. 
Descriptive statistic of Islamic banks:

Table 3. Descriptive Statistic

\begin{tabular}{lcccc}
\hline & Minimum & Maximum & Mean & Std. Deviation \\
\hline Profit & 22.40842 & 25.81488 & 2.4024011 & .38712173 \\
HR cost & 9.15017 & 25.32917 & 1.7603887 & 5.43079496 \\
Third party fund & 2.83321 & 29.99620 & 2.2419299 & 5.76312552 \\
Accounts receivable & .00000 & 28.57835 & 1.9932805 & 6.90732065 \\
Financing & .00000 & 28.61322 & 1.9222027 & 7.27351493 \\
\hline
\end{tabular}

In Table 3, the number of data used in the study was 80 with 10 BUS during 2011-2018. The average total bank profit of 2,4024011 with a minimum value of $\mathrm{Rp} 6,577$ million in BRI Islamic banks in 2014 and the highest total profit of Rp 58,367,067,139 at BCA Islamic banks in 2018.

The average personnel expense variable input of 1.7603887 the highest number of personnel expenses of Rp 100,073,030,921 at the Bukopin Islamic bank in 2017, the lowest of Rp 9,416 million in Victoria banks in 2011. Third Party Funds (DPK) averaged 2.2419299 with a maximum DPK amount of Rp4,999,797,769,586. At Bank Bukopin sharia in 2015 and a minimum DPK amount of Rp17 million in Maybank syariah in 2018. Rp17 million was obtained from wadiah demand deposits for wadiah savings and temporary syirkah funds or Rp 0 .

The average variable output of murabahah receivables is 1.9932805 with a minimum value of $\mathrm{Rp}$ 0 in Maybank syariah in 2011 to 2014 and the highest in the amount of $\operatorname{Rp} 2,578,807,458,124$ in Bukopin Islamic banks in 2012. Total average financing amounted to 1.9222027, minimum financing amounted to Rp 0 in Maybank syariah in 2011, 2012,2013 and 2018, and the highest was Rp840,259,854,571 at the Bukopin Islamic bank in 2012. This shows a low market share in mudharabah, musyarakah and murabaha Maybank syariah financing.

\section{Analysis of the Efficiency Level of Sharia Commercial Bank}

This study uses the Stochastic Frontier Approach (SFA) method to determine the level of earnings efficiency at Islamic commercial banks. Data processing using Frontier software 4.1. Following are the results of earnings efficiency with the SFA method of Islamic banks

Table 4. Efficiency Levels of Islamic Commercial Banks

\begin{tabular}{ccccccccccc}
\hline & BMI & BRIS & Jabar Banten & Panin & Mega & Bukopin & BCA & BNI & Maybank & Victoria \\
\hline 2011 & 0.79495 & 0.83523 & 0.83916 & 0.81858 & 0.78889 & 0.83429 & 0.80618 & 0.84613 & 0.83019 & 0.85971 \\
2012 & 0.79400 & 0.79400 & 0.83866 & 0.81673 & 0.78816 & 0.85331 & 0.81231 & 0.84086 & 0.83379 & 0.85507 \\
2013 & 0.79256 & 0.84065 & 0.83676 & 0.81232 & 0.78727 & 0.85928 & 0.83655 & 0.83875 & 0.83243 & 0.78918 \\
2014 & 0.78746 & 0.84005 & 0.83582 & 0.80962 & 0.78592 & 0.81375 & 0.83628 & 0.83664 & 0.84783 & 0.86193 \\
2015 & 0.78691 & 0.83924 & 0.83581 & 0.80668 & 0.78721 & 0.87909 & 0.86954 & 0.83671 & 0.85487 & 0.94701 \\
2016 & 0.78744 & 0.83888 & 0.83453 & 0.80505 & 0.79785 & 0.88741 & 0.89520 & 0.82504 & 0.85340 & 0.41278 \\
2017 & 0.78761 & 0.83881 & 0.82991 & 0.80920 & 0.80491 & 0.76069 & 0.90724 & 0.83663 & 0.85059 & 0.79427 \\
2018 & 0.78698 & 0.83931 & 0.83742 & 0.80376 & 0.80254 & 0.76809 & 0.91538 & 0.83504 & 0.84919 & 0.79939 \\
average & 0.78974 & 0.83327 & 0.83601 & 0.81024 & 0.79284 & 0.83199 & 0.85984 & 0.83698 & 0.84404 & 0.78992 \\
\hline \multicolumn{8}{c}{ Average of Islamic Bank Efficiency 0.82249 } \\
\hline \multicolumn{10}{c}{}
\end{tabular}

The level of profit efficiency of Islamic banks in general an average of 0.82249 or $82.24 \%$. This means that profit efficiency can only be obtained at $82.24 \%$ while the remaining $17.76 \%$ in financing has not been channeled. The highest average efficiency level of Islamic banks is above the average of BUS or close to 1, there are BCA Islamic banks at 0.85984 or $85.94 \%$, Maybank sharia 0.84404 or $84.40 \%$ and Bank Jabar Banten syariah at 083601 or $83.60 \%$. 
The highest level of efficiency of sharia BCA in 2018 was 0.91538 or $91.53 \%$ and the lowest in 2011 was 0.80618 or $80.61 \%$. Maybank sharia remember that the highest profit efficiency in 2015 was 0.85487 or $85.48 \%$ and the lowest in 2011 was 0.83019 or $83.01 \%$. Jabar Banten sharia level of earnings efficiency variations ranging from 0.82991 or $82.99 \%$ in 2017 to 0.83916 or $83.91 \%$ in 2011, overall the level of profit efficiency of Jabar Banten Islamic banks experienced a decline from 2011 to 2018 but the decrease in the level of efficiency not too far on average, only about $5 \%$. At BCA Islamic banks with an efficiency level above the average acquisition of DPK input variable of $R p 5,650,402,225,107$ consisting of deposits of $R p$ 621,314,486,390 and temporary syirkah funds Rp5,029,087,738,717 personnel expenses for the year Rp 92,148,860,031. On the output variable, the financing distribution is Rp. 475,121,897,606 and the acquisition of murabahah receivables is $\mathrm{Rp} 1,679,410,190,582$. This shows that with the acquisition of a number of inputs, the ability of banks to produce output reaches $3 \%$.

The average efficiency level of Islamic banks is the lowest below the average BUS, at Bank Muamalat Indonesia, Bank Victoria Syariah and Bank Mega Syariah. Based on the acquisition of SFA earnings efficiency, the efficiency level of Bank Muamalat is considered low starting in 2014-2018, the average lowest profit efficiency level in 2015 was 0.78691 or $78.671 \%$ and in 2018 it was 0.78698 or $78.669 \%$. The level of profit efficiency of the Islamic banks of Victoria is lowest in 2016 of 0.41278 or $41.27 \%$ and the highest in 2015 of 0.94701 or $94.70 \%$, the figure is almost close to 1 but in 2016 the profit efficiency of Victoria's bank has decreased. In the previous year 2011-2015 only in 2013 which decreased by 6.59\% from 2012 to the following year showed an increase in profit efficiency except 2016. Bank Mega Syariah based on the average efficiency of the SFA has values ranging from 0.78592 or $78,59 \%$ in 2014 and 0.80491 or $80.49 \%$ in 2017 . BMI in that year obtained the input of Third Party Funds amounting to $\mathrm{Rp} 48,696,807,351$ and personnel expenses of $\mathrm{Rp} 924,521,476$ financing output amounting to

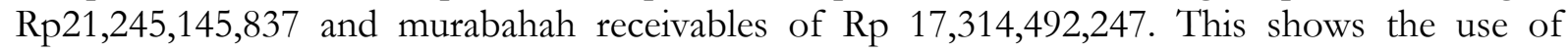
personnel expenses that are higher than the output obtained so that the output that can be achieved is only $1.2 \%$ with a profit of Rp. $74,492,188$.

Based on the results of the average efficiency of Islamic commercial banks, it can be classified the level of efficiency based on the standard deviation. The grouping of BUS earnings efficiency values into five categories using quartile percentages \pm standard deviations (Rahmawati, 2015) is as follows:

\begin{tabular}{cc}
\hline Efficiency level & category \\
\hline$<0,65$ & Not efficient \\
$0,65-0,89$ & less efficient \\
$0,89-0,97$ & nearly efficient \\
$>0,97$ & efficient \\
\hline
\end{tabular}

BUS grouping as follows:

\begin{tabular}{lcc}
\hline \multicolumn{1}{c}{ BUS } & Efficiency level & category \\
\hline Bank Muamalat & 0.78974 & Less efficient \\
BRI Syariah & 0.83327 & Less efficient \\
Jabar Banten & 0.83601 & Less efficient \\
Panin Syariah & 0.81024 & Less efficient \\
Mega Syariah & 0.79284 & Less efficient \\
Bukopin & 0.83199 & Less efficient \\
BCA & 0.85984 & Less efficient \\
BNI & 0.83698 & Less efficient \\
Maybank & 0.84404 & Less efficient \\
Victoria & 0.78992 & Less efficient \\
\hline Source: Data Processed
\end{tabular}


Based on the grouping of Sharia Commercial Bank (BUS) it can be concluded that the overall category of BUS shows less efficient. This shows the problems of Islamic banks as a whole so that there needs to be an increase in market share of financing to the community one of them by making new products based on technology. The high level of efficiency of Islamic banks is also shown in the research of Rahmawati (2015), Wahab (2015), Hosen \& Muhari (2014), Suhel (2011) and Mohamad et al (2008).

The Influence of Input-Output Variables on the Total Profit of Sharia Commercial Banks

Table 5. Estimated Total Profit Results

\begin{tabular}{lccc}
\hline & Coefficient & Standard-error & T-ratio \\
\hline Beta 0 & 0.23521 & 0.16968 & 0.13862 \\
Beta 1 & 0.04513 & 0.01871 & 0.24120 \\
Beta 2 & 0.00704 & 0.01117 & 0.63029 \\
Beta 3 & -0.00389 & 0.01644 & -0.23681 \\
Beta 4 & -0.00856 & 0.01757 & -0.48734 \\
Sigma-square & 0.15845 & 0.04165 & 0.38044 \\
Gamma & 0.44008 & 0.22057 & 0.19952 \\
Log likelihood function & -0.26498 & & \\
\hline \multicolumn{4}{l}{ Source: SFA Data Processed (2019) } \\
\hline
\end{tabular}

Data processing using software frontier 4.1. The form of the equation of profit efficiency levels as follows.

$\operatorname{Ln} \pi=0,235+0,045 \ln \mathrm{P} 1+0,007 \ln \mathrm{P} 2-0,003 \ln \mathrm{Q} 1-0,008 \ln \mathrm{Q} 2$

Based on regression equity above, the constant $\pi$ is 0.235 . This shows that if the input and output variables are considered constant, the BUS profit at a certain level of output is 0.638 million from financing. (ex $0.235=0.638$ ).

In the input variable, namely third party funds (lnP1) regression coefficient 0.045 , this shows that if third party funds have increased by $1 \%$, the total profit will increase by $0.045 \%$. This indicates that the High Third Party Fund (DPK) of Sharia Commercial Bank (BUS) gives an increase in the amount of BUS profit where the higher DPK, the profit toal will also increase. In the t-test, DPK does not affect the total profit where the t-ratio of 0.24120 is smaller than $t$-table 1.99045. The results of this study are in accordance with the research of Suhel (2011) and Effendi (2016).

The personnel load input variable (lnP2) regression coefficient 0.007 shows that if the personnel load increases by $1 \%$, the average total BUS profit will increase by $0.007 \%$. This shows the use of personnel expenses incurred by the BUS for employees in accordance with the expected performance of the BUS so that the profit earned increases annually. Statistically the personnel expense has t-ratio of 0.63029 smaller than t-table 1.99045 where the personnel expense has no effect on the total BUS profit.

In the output variable that is total financing (lnQ1) the regression coefficient of -0.003 shows that if the total financing has increased by $1 \%$, then the total profit will decrease by $0.003 \%$. This shows that the financing output channeled has a high level of non-performing financing so that the total profit has decreased. Total financing does not affect the total profit where the value of $\mathrm{t}$-ratio 0.23681 is smaller than $\mathrm{t}$ table 1.99045 . The results of this study are in accordance with the research of Suhel (2011), Effendi (2016), Rahmawati (2015), and Wahab (2015).

In murabaha receivables variable (lnQ2), the regression coefficient of -0.008 shows that if murabaha receivables increase by $1 \%$, the total profit will decrease by $0.008 \%$. Murabahah 
receivables less contribute to total BUS profit, this is due to low economic activity in which murabaha financing is one type of financing that is much in demand by the public that should be getting bigger murabahah receivables hence the high profits earned. Murabaha receivable variable does not affect the total profit with a value of $t$ ratio of 0.48734 smaller than $t$ table 1.99045 . The results of this study are in accordance with the research of Hosen \& Muhari (2014), Rahmawati (2015), Wahab (2015), and Naufal \& Firdaus (2017).

\section{Conclusion}

The results of the profit efficiency of Islamic banks with SFA method for 2011-2018 averaged 0.82249 or $82.24 \%$. The profit efficiency level of Islamic banks that are close to $100 \%$ is found in BCA syariah banks, Maybank syariah and Jabar Banten syariah banks as compared to sharia commercial banks below 100\% at Muamalat Indonesia Bank, Victoria Syariah Bank and Mega Syariah Bank.

Regression results show that third party funds and personnel expenses have a positive effect on total profits. The use of personnel expenses incurred by Islamic banks for employees in accordance with the expected performance so that the profit earned is increasing every year. Total financing and murabahah receivables have a negative effect on total profits. The acquisition of murabahah receivables is less contributing due to the low economic activity where murabahah is one of the financing that is much in demand by the public so that if the murabahah receivables are lower the profit obtained is also small.

\section{References}

Berger, A.N. \& Mester, L.J. (1997). Inside the black box: what explain differences in the efficiencies of financial institution?. Working Paper Series the Wharton School University of Pennsylvania, $\quad 97-4, \quad 1-59 . \quad$ Retrieved from: http:// citeseerx.ist.psu.edu/viewdoc/download?doi=10.1.1.41.573\&rep=rep1\&type=pdf

Effendi, Y. (2016). Measuring efficiency of the Indonesian Islamic banks. Kajian Ekonomi Keuangan, 20 (2), 133-148. DOI: 10.31685/kek.v20i2.185

Eisazadeh, S.,Shaeri, Z., \& Sina, A. (2012). An analysis of bank efficiency in the Middle East and North Africa. The International Journal of Banking and Finance, 9(4), 28-47. Retrieved from: http://ijbf.uum.edu.my/index.php/previous-issues/148-the-international-journal-ofbanking-and-finance-ijbf-vol-9-no-4-2012.

Hermawan, A. (2005). Penelitian bisnis paradigma kuantitatif. Jakarta: Gramedia Pustaka Utama.

Hosen, M.N., \& Muhari, S. (2013). Efficiency of the sharia rural bank in Indonesia lead to modified CAMEL. International Journal of Academic Research in Economics and Management Sciences, 2(5), 34-53. DOI: 10.6007/IJAREMS/v2-i5/298

Mohamad, S., Hassan, T., \& Bader, M.I. (2008). Efficiency of conventional versus Islamic banks: international evidence using the Stochastic Frontier Approach (SFA). Journal of Islamic Economics, Banking and Finance. 4 (1), 107-130. Retrieved from: http:// citeseerx.ist.psu.edu/viewdoc/download?doi=10.1.1.453.6955\&rep=rep1\&type $=\mathrm{p}$ df

Mongid, A. \& Muazaroh. (2017). On the nexus between risk taking and profitabilit: evidences from Indonesia. International Journal of Business and Society. 18 (2), 271-284. DOI: 10.33736/ijbs.483.2017. 
Muhari, S. \& Hosen, M.N. (2014). Tingkat efisiensi BPRS di Indonesia: perbandingan metode SFA dengan DEA dan hubungannya dengan CAMEL. Jurnal Keuangan dan Perbankan, 18 (2), $307-$ 328. Retrieved from: http://jurnal.unmer.ac.id/index.php/jkdp/article/view/811/460

Naufal, F.M. \& Firdaus, A. (2017). Analisis efisiensi Bank Pembiayaan Rakyat Syariah (BPRS) wilayah Jabodetabek dengan pendekatan two stage Data Envelopment Analysis (DEA). Equilibrium: Jurnal Ekonomi Syariah, 5 (2), 196- 220. DOI: 10.21043/equilibrium.v5i2.2612

Nuryartono, N., Anggraenie, T. \& Firdaus, R.S. (2012). Efficiency level of BPR: study of stochastic frontier analysis with an approach of time varying decay. International Research Journal of Finance and Economics. 85, 6-13. Retrieved from: http://www.internationalresearchjournaloffinanceandeconomics.com/

Khalifaturofi'ah, S.O. (2018). Peningkatan daya saing perbankan melalui efisiensi biaya dengan metode stochastic frontier approach, INOBIS: Jurnal Inovasi Bisnis dan Manajemen Indonesia. 1(4), 434-444. DOI: 10.31842/jurnal-inobis.v1i4.49

Rahmawati, R. (2015). Strategi peningkatan efisiensi biaya pada bank umum syariah berbasis stochastic frontier approach dan data envelopment analysis. Buletin Ekonomi Moneter dan Perbankan, 17 (4) , 457-480. DOI: 10.21098/bemp.v17i4.506

Ramadhan, A., Purnomo, D., Muhtarom, M. \& Chuzaimah, C. (2017). Mengukur tingkat efisiensi bank pembiayaan rakyat syariah dengan menggunakan Data Envelopment Analysis (DEA). CAKRAWALA: Jurnal Studi Islam, 12(2), 113-120. DOI: 10.31603/cakrawala.v12i2.1704.

Suhel. (2011). Analisis efisiensi laba pada industri perbankan syariah di Indonesia dengan pendekatan Stochastic Frontier Approach (SFA). Journal of Economic \& Development, 9 (1), 14 - 20. DOI: $10.29259 /$ jep.v9i1.4998

Tahir, I.,M., \& Haron, S. (2010). Cost and profit efficiency of Islamic banks: international evidence using the stochastic frontier approach. Banks and Bank Systems, 5 (4), 78-83. Retrieved from: https://businessperspectives.org/images/pdf/applications/publishing/templates/article /assets/3668/BBS_en_2010_4_Tahir.pdf

Wahab. (2015). Analisis faktor-faktor yang mempengaruhi efisiensi bank umum syariah di Indonesia dengan pendekatan two stage stochastic frontier aproach (studi analisis di bank umum syariah). Economica: Jurnal Ekonomi Islam, 6(2) 57-76. DOI: 10.21580/economica.2015.6.2.794. 